\title{
Constraints to the Development of Ecotourism Potentials along the Babessi-Oku Axis, North West Region of Cameroon
}

\author{
Nfor Frederick $^{1^{*}}$ and Balgah Saunders Nguh $^{1}$ \\ ${ }^{1}$ Department of Geography, Faculty of Social and Management Sciences, University of Buea, \\ P.O.Box 63 Buea, Cameroon.
}

Authors' contributions

This work was carried out in collaboration between both authors. Authors NF and BSN designed the study, performed the statistical analysis, wrote the protocol and wrote the first draft of the manuscript. Author NF assisted in data collection and analyses of the study. Both authors read and approved the

final manuscript.

Article Information

DOI: $10.9734 / A J G R / 2020 / v 3 i 430112$

Editor(s):

(1) Dr. Xu Chong, Institute of Geology, China Earthquake Administration, China.

Reviewers:

(1) Fitri Damayanti, Indraprasta PGRI University, Indonesia. (2) Girijesh Singh Mahra, ICAR-Indian Agricultural Research Institute, India. Complete Peer review History: http://www.sdiarticle4.com/review-history/60754

Original Research Article

Received 20 June 2020

Accepted 26 August 2020

Published 04 September 2020

\begin{abstract}
Tourism has become one of the world's largest industries, with an estimated US\$ 3 trillion in annual revenues and expanding at an average rate of 4-5 per cent annually. Since the 1950s, the global market for international travel and tourism has exhibited uninterrupted growth. As the world is becoming a global village, (eco) tourists are looking for new attractions and these are well represented in Cameroon at large and in the Bamenda Highlands in particular. The Bamenda Highlands, on which the Babessi-Oku Axis is found, is one of the most spectacular ecotourism destinations in the country characterized by gentle undulating hilly savanna, patches of forest, lakes, waterfalls, mountains and an amazing cultural diversity. The main objective of this study was to examine the constraints to the development of ecotourism sector along the Babessi-Oku Axis and to develop a sustainable ecotourism management model to address these constraints. Data for this study were obtained through primary and secondary sources. Primary sources of data included: personal interviews, field observation, the use of camera, Geographic Positioning Systems (GPS), questionnaires and the use of Focus Group Discussions (FGDs). Secondary sources included:
\end{abstract}

*Corresponding author: E-mail: nforfred@yahoo.com; 
materials from published and unpublished works related to the current study, maps and the exploitation of aerial photographs. Findings revealed that there are a plethora of constraints plaguing the ecotourism sector along the Babessi-Oku Axis and these include: degradation of the Oku Montane Forest, poaching, forest destruction for agricultural purposes, extinction of fauna biodiversity, and lack of community participation among others. An ecotourism development model for the study area has been developed in order to sustainably address these ecotourism constraints along the Babessi-Oku Axis.

Keywords: Ecotourism; Oku Montane Forest; constraints to ecotourism development; ecotourism development model.

ACRONYMS

$\begin{array}{ll}\text { MINTOUR } & : \begin{array}{l}\text { Ministry of Tourism } \\ \text { and Leisure }\end{array} \\ \text { OMF } & : \begin{array}{l}\text { Oku Montane Forest } \\ \text { ICBP }\end{array} \\ & : \begin{array}{l}\text { International Council } \\ \text { for Bird Preservation }\end{array}\end{array}$

\section{INTRODUCTION}

Tourism has become one of the world's largest industries, with an estimated US\$ 3 trillion in annual revenues and expanding at an average rate of 4-5 per cent annually. Since the 1950s, the global market for international travel and tourism has exhibited uninterrupted growth. After the end of the Cold War, the sector accelerated more rapidly than the global economy, with an average annual growth rate of 4.1 per cent between 1995 and 2010 [1,2]. Ecotourism is a leading industry in the world today and offers economically viable options for ecosystem protection while also providing jobs and supporting community development [3].

In Africa, the ecotourism industry plays an increasingly important role in the economy, contributing 5 per cent of Gross Domestic Product (GDP), 30 per cent of service exports, and 235 million jobs. Indeed, each year, approximately 1 billion people travel internationally. By 2030, consumer spending on tourism, hospitality, and recreation in Africa is projected to reach about $\$ 261.77$ billion, $\$ 137.87$ billion more than in 2015. From 1998 to 2015, service exports, including "industries without smokestacks" such as tourism, have grown about six times faster than merchandise exports in Africa [4]. The African Development Bank (AfDB) estimates that, in 2015, Africa received 62.5 million visitors, contributed 9.1 million direct jobs in travel and (eco)tourism sectors, and generated $\$ 39.2$ billion in international (eco) tourism receipts. While the international (eco) tourist arrivals on the whole continent increased by nearly 36 million between 2000 and 2017 , the sub-Saharan region has experienced the lion's share of this growth (24.7 million) [2].

Cameroon, geographically located within the sub-Saharan region and christened as 'Africa in miniature', demonstrates significant potential for ecotourism development. Due to Cameroon's rich biodiversity, it represents almost all ecotones found in Africa including a very wide variety of landscape patterns $[5,6,7]$. With a largely intact flora and high fauna diversity, the country is an ecotouristic haven par excellence $[8,9,10,11]$. In addition, Cameroon presents a good picture of sub-Saharan Africa region with respect to cultural diversity-having over 250 cultural groups [12]. In terms of ethnic diversity, Cameroon's ethnic fractionalization score $(0.89)$ exceeds the subSaharan African average of 0.64 [13]. According to Kimbu [14], the Cameroon government is committed to prioritizing the development of the tourism sector as a vehicle for stimulating local economic development, especially in areas lacking mineral resources. The national government, through the Ministry of Tourism and Leisure (MINTOUL), is in charge of the tourism policy, the development of tourist attractions, the provision of training, and tourism marketing. The existing official data show that Cameroon received 572,728 international tourists in 2010 and expanding to over 900,000 by 2015 [15]. This makes Cameroon a tourism destination country as the total number of tourists received surpassed the 500,000 mark required by the United Nations World Tourism Organisation standards.

As the world is becoming a global village, (eco)tourists are looking for new attractions and these are well represented in Cameroon at large and in the Bamenda Highlands in particular. The Bamenda Highlands, on which the Babessi-Oku Axis is found, is one of the most spectacular ecotourism destinations in the country characterized by gentle undulating hilly savanna, 
patches of forest, lakes, waterfalls, mountains and an amazing cultural diversity Lambi $[16,17]$. Ecotourism holds immense potential along the Babessi-Oku Axis as a viable economic alternative and a strategy to protect its globally significant rainforests and cultural heritage.

\section{THE STUDY AREA AND THE PROBLEM BACKGROUND}

The Babessi-Oku Axis is located between latitudes $05^{\circ} 54^{\prime} \mathrm{N}$ and $06^{\circ} 16^{\prime} \mathrm{N}$ of the equator and longitudes $10^{\circ} 24^{\prime} \mathrm{E}$ and $10^{\circ} 40^{\prime} \mathrm{E}$ of the Greenwich Meridian. This region is bounded to the North by Noni, West by Belo, South by Ndop and East by Jakiri Sub-divisions (Map 1) and covers a surface area of approximately 612.50 $\mathrm{km}^{2}$. The area has a warm climate in the flood plains of Babessi and a cold climate in the high elevations of Oku. Considered as one of the hottest parts of the western plateau of Cameroon, the flood plain experiences tropical climatic conditions. The diverse land form ranging from the mountain (Mount Oku), valleys and plains (in Babessi) and the increasing anthropogenic activities and built up environment have contributed significantly in carving out the region's micro climatic condition [18]. The highlands around Oku receive a mean annual rainfall of more than 2,000 mm with August and September as the wettest months. Babessi Subdivision which is part of the Ndop Plain has an annual rainfall averaging $1,500 \mathrm{~mm}-2,000 \mathrm{~mm}$. The mean annual temperature of the study area

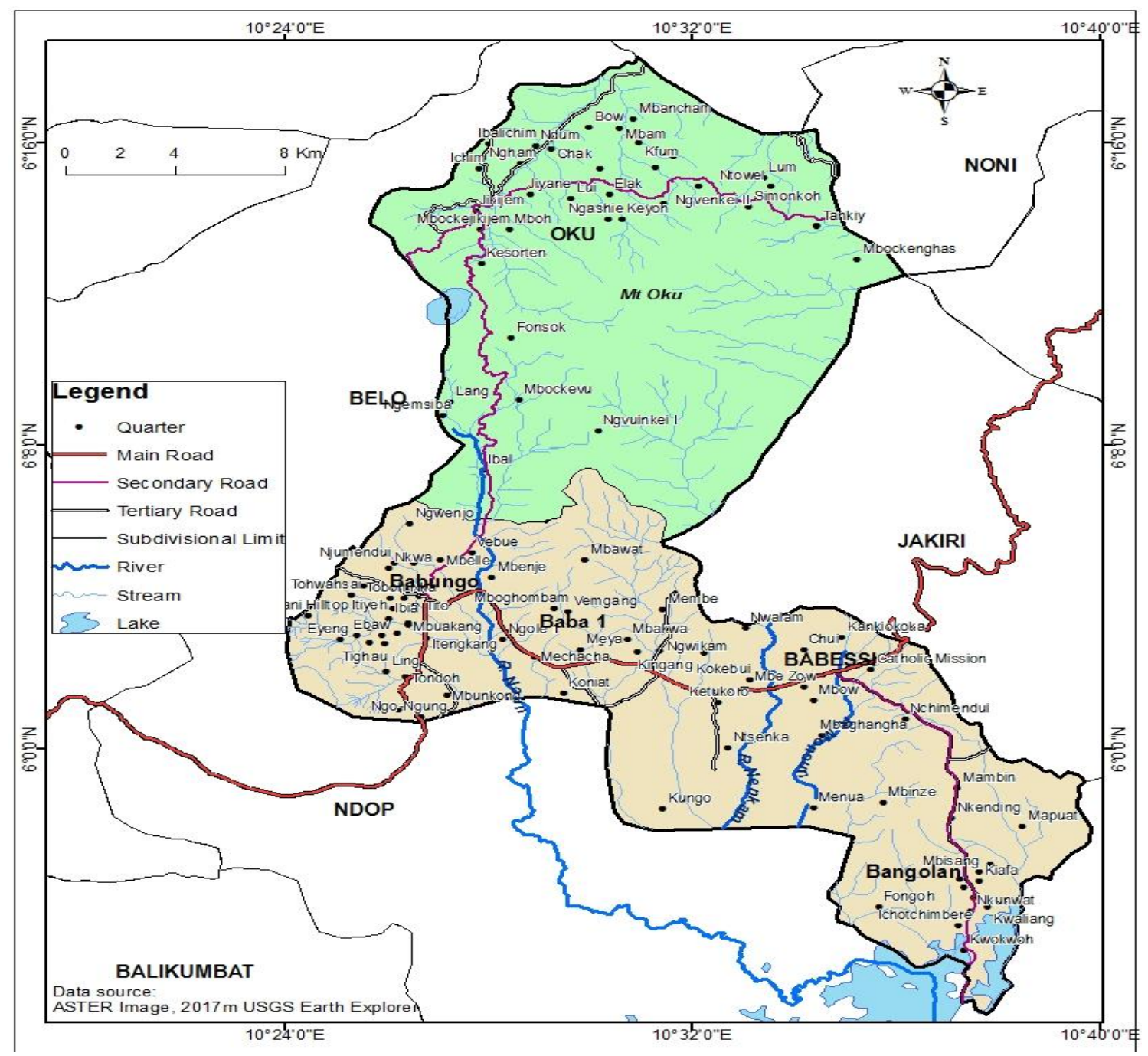

Map 1. Spatial layout of Babessi-Oku Axis Source: ASTER Image, 2017 m, USGS Earth Explorer 
varies with season, altitude and population density. On average basis, high elevated areas especially around Mount Oku have annual temperature of $20^{\circ} \mathrm{C}$ and diurnal ranges of 2$3.5^{\circ} \mathrm{C}$ while the average annual temperature of the plains is about $22^{\circ} \mathrm{C}$ [19]. These climatic variations along the Babessi-Oku Axis is a boost to ecotourism activities as most (eco) tourists visit at the beginning of the rainy season in order to enjoy the greenery of the plains and the mountain slopes. Also, most cultural activities are often programmed towards the end of the year (in the dry season) so that cultural outdoor manifestations can go on unperturbed.

The study area has a total population of 136,928 [20] and is estimated to reach 137,219 by 2025 . The region has a total of 39 villages (4 in Babessi and 35 in Oku Sub-division). All these villages are headed by traditional rulers most of them second class Fons. The people are further governed through quarter heads who are appointed by the Fons of their respective villages. The people of this region are reputably very welcoming and this accounts for the warm reception accorded to strangers. This is an impetus to ecotourists visiting this region as a result of the high degree of hospitality. This is exemplified in the number of non-indigenes who reside in the heart of the region.

\section{MATERIALS AND METHODS}

Data for this research were obtained through primary and secondary sources. Primary sources of data included: personal interviews, field observation (primary data procedure), the use of camera, Geographic Positioning Systems (GPS), questionnaires and the use of Focus Group Discussions (FGDs). Secondary sources included: materials from published and unpublished works related to the current study, maps and the exploitation of aerial photographs. Concerning the constraints to ecotourism development a likert scale was used and data were gathered from strongly agree to strongly disagree. These were then collapsed and the percentages calculated. Also, other secondary sources included office registers, statistics and figures, research reports, seminar reports, reports from international organisations. Data collected was inputted into databases using the Statistical Package for Social Sciences (SPSS Version 20 and Microsoft Excel), cleaned and analyzed using statistical, quantitative and qualitative analyses. Also, Geographic
Positioning System (GPS) and Quantum Arc Geographic Information System (QArc GIS) version 3.6 were used to geo-reference the base map of the study area.

\section{RESULTS}

Despite the advantages of ecotourism development, some areas cannot develop (eco) tourism because of some environmental and human constraints. In areas where ecotourism development is successful, it provides considerable economic benefits and its rapid expansion also has detrimental environmental and socio-economic impacts. Natural resource depletion and environmental degradation associated with (eco) tourism for example are often serious problems in (eco) tourism rich regions such as along the Babessi-Oku Axis. Table 1 presents the constraints to ecotourism development along the Babessi-Oku Axis.

Findings from the field reveal that among the community drivers of the environmental degradation that are a constraint to ecotourism development include: degradation of the Oku Montane Forest (which tops the list with $14.4 \%$ of the population in the region attesting to it), followed by a combination of other human driven causes with $11.9 \%$, destruction of wetlands (10.8\%), and poor infrastructure (7.5\%) as indicated on Table 1. Other community drivers include destruction of the forest for fuel wood and building materials $(8.2 \%)$, forest destruction for agricultural purpose $(7.7 \%)$, over grazing $(6.2 \%)$, poaching $(5.2 \%)$, and commoditization $(5.7 \%)$ among others.

\subsection{Degradation of the Oku Montane Forest (OMF)}

It is worth noting that the tropical environments host most of the world's poorest human populations, whose growth rates have remained phenomenal since the twentieth century. The results of the rapid growth in these populations have been mounting pressure on their immediate physical environment. This has given rise to phenomenal land degradation, environmental dereliction, and consequent severe biodiversity loss. This was the fate of the OMF prior to conservation efforts in the early 1990s. Before 1993, this burgeoning population was a major threat to the forest through such activities as farming, hunting, grazing, and the harvesting of Non-Timber Forest Products (NTFPs) (Table 1). 
Table 1. Constraints to ecotourism development

\begin{tabular}{|c|c|c|c|c|c|c|}
\hline \multirow[t]{2}{*}{ Constraints to ecotourism potentials } & \multicolumn{2}{|c|}{ Babessi } & \multicolumn{2}{|c|}{ Oku } & \multicolumn{2}{|c|}{$\begin{array}{l}\text { Average for } \\
\text { the region }\end{array}$} \\
\hline & $\mathbf{F}$ & $\%$ & $\mathbf{F}$ & $\%$ & $\mathbf{F}$ & $\%$ \\
\hline \multicolumn{7}{|l|}{ Environmental constraints } \\
\hline Degradation of Oku montane forest & 6 & 4.3 & 50 & 20.2 & 56 & 14.4 \\
\hline Poaching & 5 & 3.6 & 15 & 6 & 20 & 5.2 \\
\hline Forest destruction for agricultural purpose & 10 & 7.1 & 20 & 8.1 & 30 & 7.7 \\
\hline Extinction of fauna biodiversity & 3 & 2.1 & 14 & 5.6 & 17 & 4.4 \\
\hline Forest destruction for fuel wood and building material & 12 & 8.6 & 20 & 8.1 & 32 & 8.2 \\
\hline Destruction of wetlands & 40 & 28.6 & 2 & .8 & 42 & 10.8 \\
\hline Overgrazing & 17 & 12.1 & 7 & 29.8 & 24 & 6.2 \\
\hline Climate change & 3 & 2.1 & 10 & 4.0 & 13 & 3.4 \\
\hline $\begin{array}{l}\text { Harvesting of Prunus Africana and other medicinal } \\
\text { herbs }\end{array}$ & 4 & 2.9 & 15 & 6 & 19 & 4.9 \\
\hline \multicolumn{7}{|l|}{ Human constraints } \\
\hline Lack of community participation & 7 & 5 & 17 & 6.9 & 24 & 6.2 \\
\hline Poor infrastructure and inaccessibility & 11 & 7.9 & 18 & 7.3 & 29 & 7.5 \\
\hline Commoditization & 7 & 5 & 15 & 6 & 22 & 5.7 \\
\hline Others & 11 & 7.9 & 35 & 14.1 & 46 & 11.9 \\
\hline
\end{tabular}

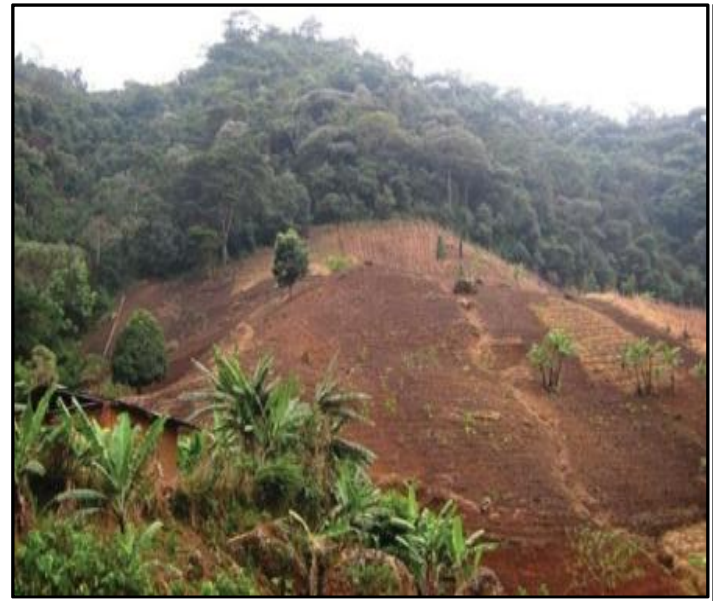

(A)

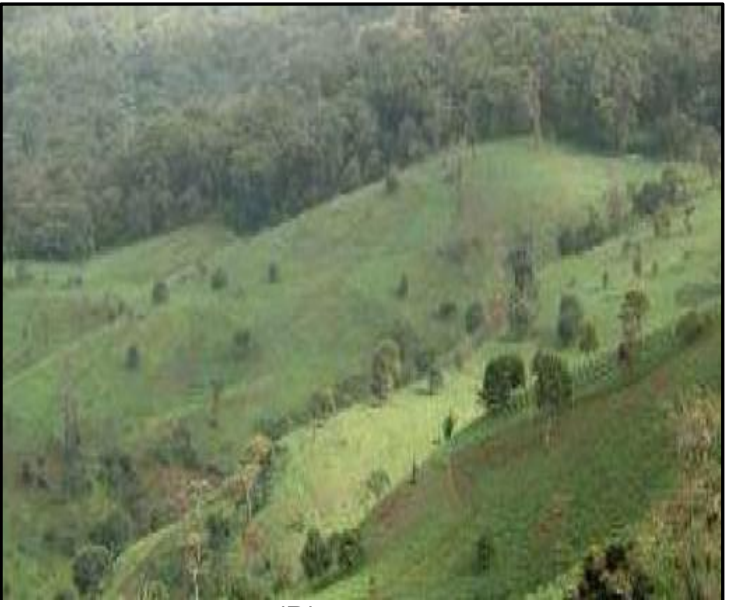

(B)

Plate 1. The encroachment of farmlands (A) and grazing land (B) into Oku montane forest due to constant population pressure and the need to feed to the ever increasing mouths

Generally, forest resources occupy approximately 22 million hectares of Cameroon's territory. However, the country is experiencing increasing deforestation rates, with an estimated 200,000 hectares of forest lost annually, mainly through deforestation for economic reasons (timber and agricultural activities). This rate of forest loss is however, not uniform throughout the country. In particular, the rate is higher in the North western Highlands (where the OMF is located) of Cameroon, which host a population of over 1,500,000 inhabitants. Along the BabessiOku Axis, about 200,000 people are living within a day's walk of the forest. This dense population accounted for the high pressure on the forest, especially farmlands, resulting in rapid forest degradation. But as of 2018, the area occupied by the farmland slightly reduced while that for settlement instead increased. This is due to population pressure and the need for more houses to settle the ever growing population.

Given that more than $80 \%$ of this population relies on crop production and livestock grazing (principally cattle, sheep, and goats) as their basic sustenance, there has been growing pressure on the forest to carry out these activities. The location of the OMF, on the 
second highest mainland peak in West Africa, naturally predisposes it to degradation threats such as soil erosion, landslides, torrential rains, and high rainfall intensities, among others. However, with the growing human populations around this forest at the dawn of the Twentieth Century, the degradation of the forest was accentuated by mounting anthropic activities, especially extensive peasant farming, grazing, hunting, and the excessive exploitation of forest products. This was aggravated by the high population density of both humans and livestock, especially cattle. The creation of the new farmlands (Plate 1A) and grazing lands (Plate $1 \mathrm{~B})$ resulted in growing forest degradation, which exposed the soils to the ugly, sculpturing hands of erosion and caused general environmental degradation of these highlands (Plate 1A). All these are detrimental to ecotourism development as the wearing of the forest has chain effects on plant and animal lives which are the core elements that attract ecotourists to the montane forest.

As a result of the rapid population growth and associated anthropic activities, the size of the OMF, which was estimated at 17,500 hectares in 1963, was reduced to 10,500 hectares by 1986 . This rapid recession of the forest is equally attributed to the conservators' several failed attempts to gazette the forest as a protected area until the 1980s. Given these disquieting human activities in this area, the OMF continued to suffer from trauma and biological holocaust, as demonstrated by the replacement of forest ecosystem with grassland ecosystems, which are being utilized as farming and free range grazing sites. Table 2 shows the calculated values of land use along the Babessi-Oku Axis in 1980, 2010 and 2018 using processed Landsat images for the above mentioned years.

Between 1963 and 1986, the OMF reduced by 7,000 hectares and thanks to the prompt intervention of the Cameroon government and the Birdlife International that brought in conservation strategies to save this natural forest from continuous degradation. The results of their efforts were fruitful as the primary forest increased from $41.87 \mathrm{~km}^{2}$ in 1980 to $56.78 \mathrm{~km}^{2}$ in 2000 (Table 2). Unfortunately, the surface area of the primary forest has dropped to $51.41 \mathrm{~km}^{2}$ in 2018 owing to the fact that the mission of the BirdLife International in their conservation efforts came to an end in 1994. The conservation efforts of the OMF was then handed to the Cameroon government and the local authorities but unfortunately, there was so much laissez faire in conservation efforts leading to continuous deforestation of the primary forest as indicated on Table 2.

The trend of the secondary forest on it part has been on a continuous decrease from $61.6 \mathrm{~km}^{2}$ (1980) to $53.91 \mathrm{~km}^{2}(2000)$ and $49.63 \mathrm{~km}^{2}$ (2018) as illustrated on Table 2 . In that same line, the surface area covered by wetland, grassland and farmland have also been in a decrease since 1980 but that of settlement has been on a constant rise from $15.58 \mathrm{~km}^{2}(1980)$ to $23.19 \mathrm{~km}^{2}$ (2000) and to $31.56 \mathrm{~km}^{2}$ in 2018 (Fig. 1).

The increase in the surface area of settlement land has been attributed to increase in the population and the need to construct new houses to accommodate the increasing population. It should be noted that the trend in land cover of rice field has been on a continuous increase that is from $13.80 \mathrm{~km}^{2}$ (1980) to $23.68 \mathrm{~km}^{2}$ (2000), and to $27.68 \mathrm{~km}^{2}$ in 2018 . This is because of the presence of the agro-industrial complex (Upper Noun Valley Authority-UNVDA) established in Ndop whose desire is to expand their farms as much as they can do. Some rice farmers also go in search of wetlands to cultivate their rice thereby increasing the surface area of rice field over time while that for wetland is on a constant decrease as seen on Table 2. The volume of water resources over the years has remained relatively stable. As can been seen on Table 2 farmland is the only indicator that has been on a constant decrease despite all the rate of deforestation by the farmers. This is because parts of the farmlands have been engulfed by human settlement. It should be highlighted that settlement has been increasing consistently from 1980 to 2000 to 2018 , with $15.28 \mathrm{~km}^{2}, 23.19 \mathrm{~km}^{2}$ and $31.56 \mathrm{~km}^{2}$ respectively. At the same time, secondary forest has been decreasing consistently with $61.6 \mathrm{~km}^{2}, 53.91 \mathrm{~km}^{2}$ and 49.63 $\mathrm{km}^{2}$ respectively. The decrease in land use land cover for secondary forests has a direct link with the condition of flora and fauna biodiversity through habitat destruction and the overexploitation of these species.

\subsection{Poaching on Oku Montane Forest}

Rural communities in forest fringes all over the world depend on the forest resources for livelihood because forest ecosystems are abodes of resources on which social life and economic development are anchored. Apart from general land degradation in and around the OMF, the loss of mega fauna, including species such as 
leopards, elephants, buffaloes, and antelopes can be attributed to the indiscriminate hunting as opined by $5.2 \%$ of the population (Table 1 ). From 1987 to 1998 , chimpanzees were completely wiped out in the OMF. This massive hunting which has been backed by the culture and tradition of the adjacent tribal communities, accounts for the present small number of large mammals, limited to Preuss's guenon (Cercopithecus preussi), green monkey (C. aethiops tantalus), African civet (Viverra civetta), serval (Felis serval), and duikers (Cephalophus spp.). Unfortunately, a good number of these mammals are at the point of regional extinction which may further cripple the ecotourism sector in this area.

Also, the hunting of red feather tauracco is a call for concern. Hunting of wild animals and birds on the OMF was going on unperturbed until when the forest was declared a reserve in 1987. Hunting in the reserve was prohibited from 1994 when the Kilum Mountain Forest Project was created and this decision was reinforced by forest patrollers of the forest project that BirdLife International instituted to track down culprits hunting the culturally cherished bird, Bannerman taurraco whose feathers are used to crown those who kill a leopard or decorate elites that have contributed greatly in the development of the village. The need for using the red feathers of Bannerman taurraco as a symbol of recognition for hard work has gone a long way to degrade the numbers of tauracco and is already being short listed as a threatened species by the International Council for Bird Preservation (ICBP) and of course a deterrent to ecotourism sector along the Babessi-Oku Axis.

Table 2. Calculated area coverage of land use for 1980, 2000, and 2018 (area in $\mathbf{k m}^{2}$ )

\begin{tabular}{lllll}
\hline No & Land use & $\mathbf{1 9 8 0}$ & $\mathbf{2 0 0 0}$ & $\mathbf{2 0 1 8}$ \\
\hline 1 & Settlement & 15.58 & 23.19 & 31.56 \\
2 & Rice field & 13.80 & 23.68 & 27.68 \\
3 & Farmland & 178.75 & 274.6 & 264.47 \\
4 & Primary forest & 41.87 & 56.78 & 51.41 \\
5 & Secondary forest & 61.6 & 53.91 & 49.63 \\
6 & Grassland & 215.36 & 148.01 & 121.62 \\
7 & Wetland & 40.07 & 31.01 & 29.37 \\
8 & Water & 6.82 & 6.83 & 6.82 \\
\hline Total & & $\mathbf{5 8 2 . 5 6}$ & $\mathbf{5 8 2 . 5 6}$ & $\mathbf{5 8 2 . 5 6}$ \\
\hline \multicolumn{4}{r}{}
\end{tabular}

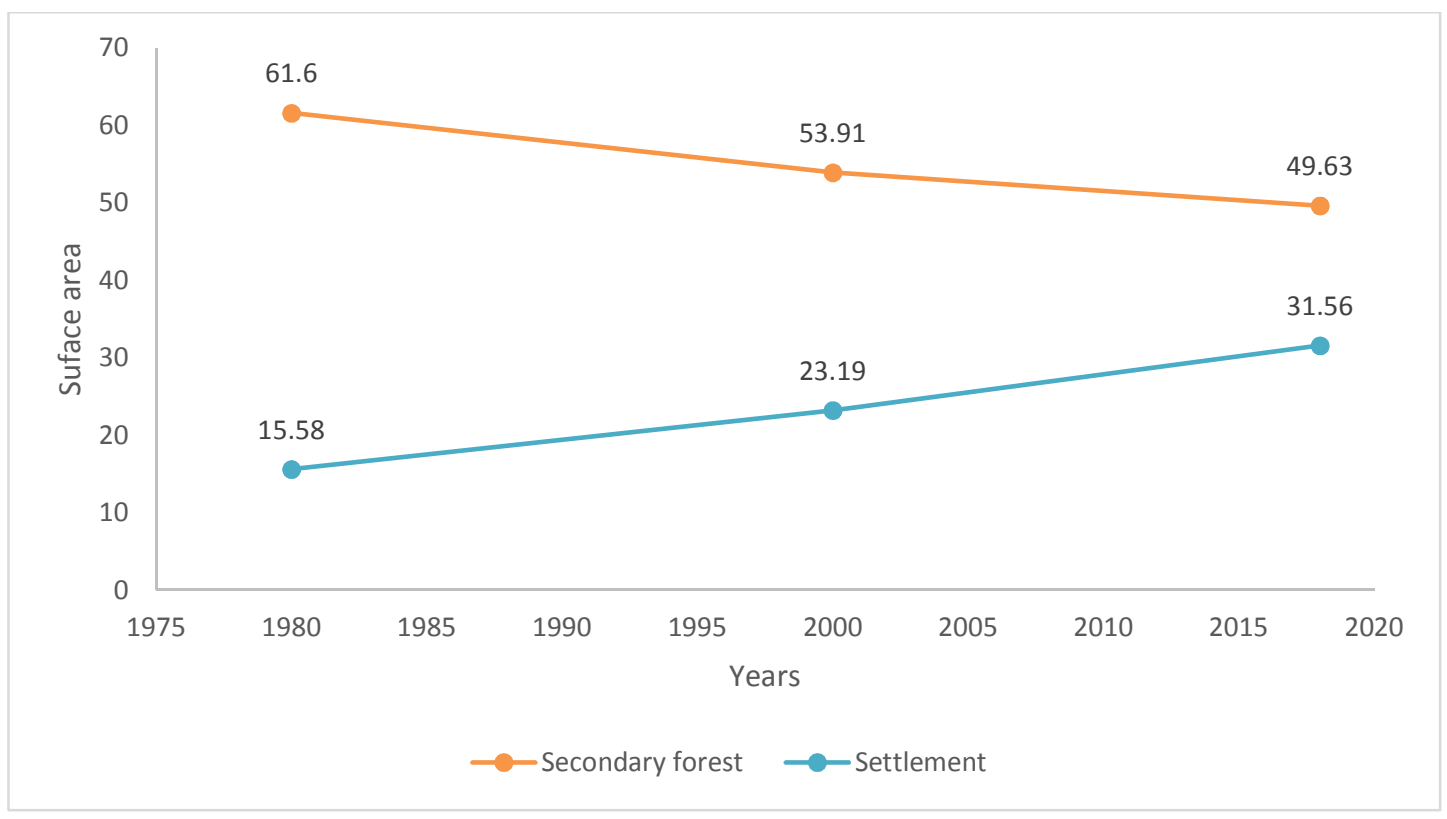

Fig. 1. Trends in secondary forest and settlement between 1980 and 2018 


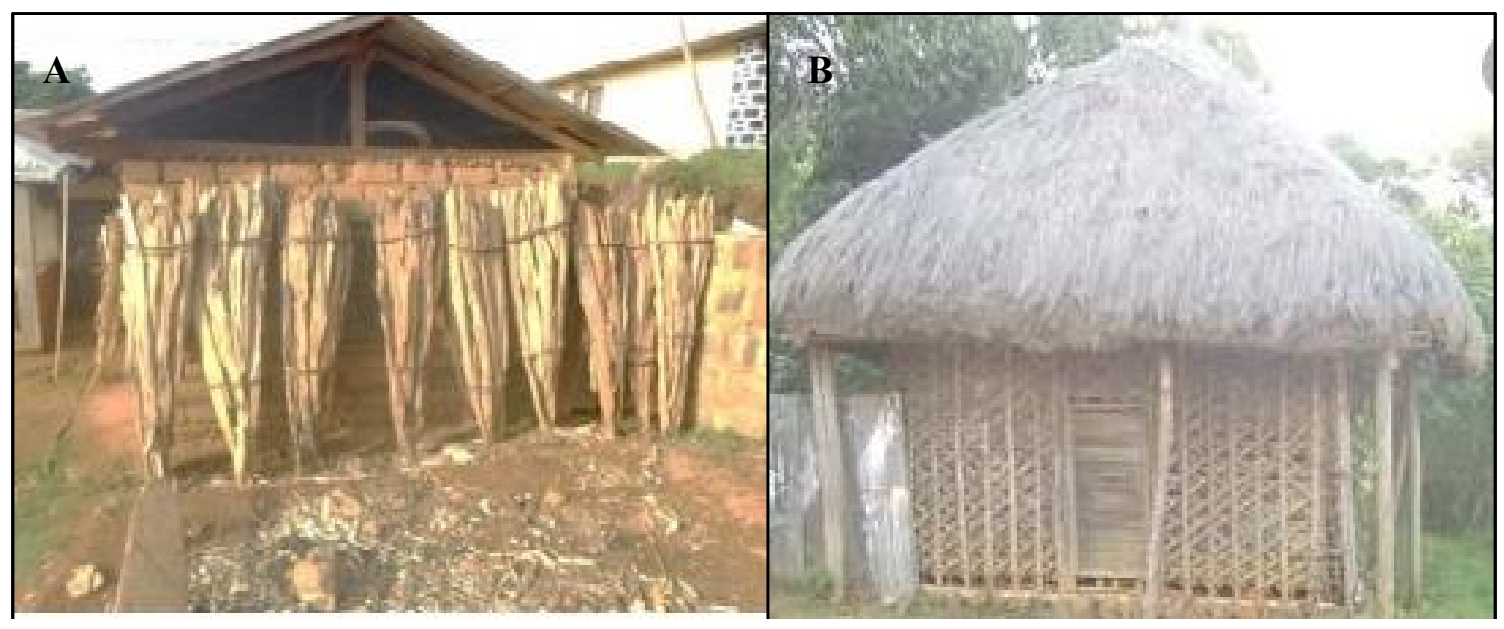

Plate 2. Forest wood for fuel and a house constructed with bamboos

\subsection{Forest Wood for Fuel and Building Material Purposes}

Field survey reveals that about $90 \%$ of the people living along the Babessi-Oku Axis use firewood as a source of fuel. The villages that surround the forest naturally are forestdependent for fuel wood.

In the villages surrounding the forest, some household members harvest forest wood mainly for domestic use whereas others harvest the forest wood for commercial purposes (Plate 3A). On the contrary, field work (2019) noted that villages located further away from the forest like those in Mbam zone and lower Shingah depend on dry palm bamboos, eucalyptus and other tree species as a source of fuel and building materials (Plate 3B). Indian bamboo are also harvested and used as fuel wood. The danger here lies in the indiscriminate harvesting of the wood and less attention is being paid to plant species that are either endangered or being threatened. This of course risks the existence of such plant species and its subsequent availability for ecotourism development in the future.

\subsection{Forest Destruction for Agricultural Purposes}

Forest users remarked that since 1970, forest destruction due to encroachment by agriculture has been rampant. Cultivation is advancing up to a height of about $2,200 \mathrm{~m}$, almost reaching the Lake crater rim. Increase in demographic pressure combined with improved market access has meant that farmers are cropping more intensively than before and the traditional system of bush-fallowing for $10-15$ years is faltering. This has been attested by $7.7 \%$ of the population. The result is that soil fertility is becoming exhausted, crop yields are poor and forest lands are being rapidly cleared to augment existing farms of declining fertility. This is the major reason for the forest destruction.

Traditionally, land was allocated by the chief and the traditional councils of each village. The lack of strict rules and regulations coupled with poor protection efforts of the government has led to much confusion about land rights. This has resulted to an influx of 'outsiders' who have illegally claimed forest land as their own, either employing local labour to farm it or renting them out. This has led to so many individuals owning lands and patches of forests as attested by the population. Moreover, fire also constitutes one of the major threats to the forest. During the dry season of $1984 / 1985$ about 1600 hectares of forest above Simon Kov village was affected by fire, leaving a $50-80 \%$ of canopy dead. Many fire damaged areas are used to cultivate beans, potatoes and cocoyam up to about $2,600 \mathrm{~m}$ above sea level. Such sites include Ngongba forest, Vekovi and Wvem. Most of the fire is initiated by farmers, grazers, wild honey harvesters, hunters and even children.

\subsection{Over Grazing}

The presence of about 1,100 sheep, goats and cattle on the Summit of Mount Oku creates several issues. First of all, the consumption of plants by the animals reduces rare plants. The reduction of plant matter reduces the structure of the habitat for organisms that would depend on 
for shelter. This has been attested by $6.2 \%$ of the population (Table 2). The physical presence of livestock causes trampling of vegetation and compaction of the soil. The reduction of vegetation through both grazing and trampling kills or weakens the plants and their root systems that stabilize the soil. This reduces the ability of the soil to hold water resulting in increased flow of rainwater causing soil erosion, flooding and runoff.

This situation is clearly observed with the illegal grazing activities of graziers who continue to torpedo the conservation of the OMF. Despite government's regulations that forbid grazing within the forest, the native and Fulani graziers have been consistently breaking the rules and destroying the forest with the tacit approval of some individuals who ought to have stopped them. This problem is further accentuated by the inter-village and inter-fondom conflicts in the region. It should be noted that the growing resource scarcities in Bui Division where the Kilum Forest is located have made the area a hotbed for inter-tribal and inter-village conflicts over farmlands and grazing lands. The scarcities of farmlands and grazing lands have thus pushed some persons into forest boundaries. Although these conflicts are partly linked to socio-political and traditional motives, the occurrence of these conflicts around forest land indicates that they are closely linked to the need for more fertile farmlands and flourishing vegetation for livestock especially during the dry season. All these of course put pressure of ecotourism resources especially the vegetal resources.

\subsection{Extinction of Fauna Biodiversity}

The fauna biodiversity that thrived some time in this region was as a result of the favourable ecosystems and habitats that existed in the form of swamp forests. Macro fauna species of birds, reptiles and mammals in the years before the 1970s thrived in this region. This was evident when interviewing hunters and visiting palace museums of villages in this region. Over 18 local names were given for different fauna species that used to exist but have all disappeared from the region, examples include: elephants, gorillas, cheetahs, crocodiles, monkeys, waterbuck, amongst others. However, lessons learnt on the field from hunters and relics seen in the palaces proved that the biodiversity in this region was quite rich. This explains why hunting was an important activity in this region. During the 1960s, the biodiversity was quite abundant and large mammals were available but later during the decades after the 1990s, most of these species got extinct. At least one species of Great Blue Turaco (Corythaeola cristata) last seen in the region in 1984 may have disappeared due to deforestation.

\subsection{Destruction of Wetlands}

Due to increase in population and the need to feed the ever increasing mouths and to settle the ever burgeoning population, the wetlands along the Babessi-Oku Axis have been on a decline for many years now. This decline has been from $40.07 \mathrm{~km}^{2}$ (1980) to $31.01 \mathrm{~km}^{2}$ (2000) to 29.37 $\mathrm{km}^{2}$ in 2018 (Table 2). New farms are being opened every day and marshes are being reclaimed for agricultural and settlement purposes. Consequently, habitat destruction and changes of most basic features of wetlands such as water retention, hydrologic function are distorted. Fig. 2 shows long term effects on anthropogenic activity on the wetlands and fauna especially in Babessi Sub-division.

In the 1960s for example, was the period during which the fauna biodiversity in the wetlands was abundant and in tack. Very huge animal species existed alongside and including: buffaloes, hippopotamus, lions, water bugs and elephants. The period from 1970 to 1980 was the period in which several activities were introduced (for the example, the establishment of the UNVDA in 1985) threatening animal habitats, for example rice cultivation. The largest fauna species that existed include duckers, gazel, pangolins and monkeys (Fig. 2). Between the years 1990 and 2000 , several fauna species exited and only a few migratory species occasionally came into the area and from 2000 to present, all the huge animal species that existed in the 1970s are no longer there and today, mostly avers and Pisces dominate. This deterioration of the biodiversity is a big constraint to the ecotourism sector along the Babessi-Oku Axis. It should be noted that nowadays, the introduction of more productive fish, rice, maize and tomatoes species in the area has led to overall reduction of habitat diversity due to strong competition.

\subsection{The Non-respect of Laws Regulating the Harvesting of Medicinal Plants}

There is an international conservation policy and regulation that checks the exploitation and exportation of medicinal plants especially Prunus 
africana. In Cameroon, there are regulations applying to the harvesting of Prunus africana bark reflected in management plans developed in collaboration with local extraction industries and the ministry of Forestry and Wildlife (MINFOF). Cameroon became a party to the 1973 Convention on International Trade in Endangered Species of Wild Fauna and Flora (CITES) in 1981. The Convention was enacted into Cameroonian law by Decree No. 2005/2869/PM of 29 July 2005
"Fixing the modalities of the application of certain dispositions of the CITES Convention in Cameroon, and Decision $N^{\circ}$ 0104/D/MINFOF /SG/DF/SDAFF/SN of $2^{\text {nd }}$ March 2006 designating National Forestry Development Agency (ANAFOR) as the CITES Scientific Authority for plants. Arrêté No 067/PM of 27 June 2006, prescribed the organisation and functioning of the Inter-ministerial committee of coordination and monitoring of the implementation of CITES.

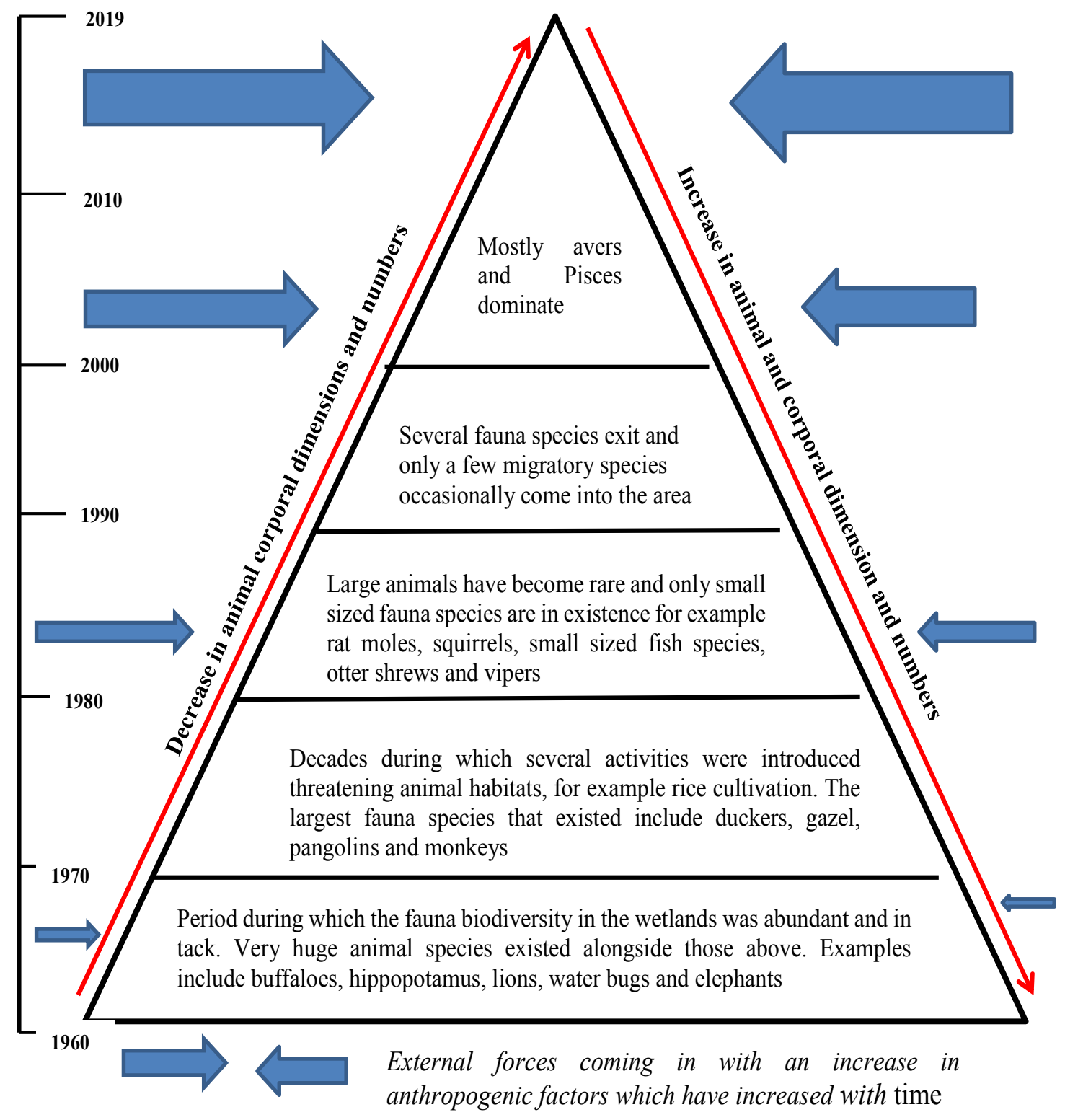

Fig. 2. Changes in biodiversity on the wetlands in Babessi Sub-division as a result of anthropogenic activities over time

Source: Adapted and Modified after Kometa [21] 
The Convention on International Trade in Endangered Species of Wild Fauna and Flora (CITES) helps regulate the sustainable exploitation of natural products in source countries, their export and entry to external markets. It is worth noting that since 1995, the exploitation of Prunus africana was band in Cameroon after rampant cases of unsustainable harvest were observed. The significant aspect of the existing regulations and quotas for sustainable harvesting, as far as the conservation of the species is concerned is that, harvesting regulations are not fully effective in area were Prunus africana is currently being exploited. Although procedures for exploiting Prunus africana remains same as in the 1981 Forestry Law, the 1994 Law (94/01) introduced two major changes for all special forest products: First, the applicant must be granted approval for forest exploitation (section 41of the law) from the Prime Minister's office, and then seek permission from the Ministry of Forestry and Wildlife, creating a two tiered system of control. Secondly the Provincial chief of forest must provide a technical report which specifies the species and quantities to be exploited, the area in which exploitation will take place and the harvesting modalities to be used (article 59 [2b] of decree of application). This Law does exist but it implementation on the field is where the problem lies. It is for this reason that there is rampant and uncontrolled harvesting of Prunus africana in the region especially on the OMF leading to it constant degradation. This has been attested to by $4.9 \%$ of the population.

\subsection{Commoditization}

Commoditization was also identified as one of the constraints to ecotourism development along the Babessi-Oku Axis as opined by $5.7 \%$ of the population. Commoditization according to the World Ecotourism Summit Final Report [22] refers to the degradation of the intrinsic value of cultural items, beliefs, goods, and practices, and may even refer to treating a human being as a good for sale. During an interview with $\mathrm{Pa}$ Ngek in Jinikejem-Oku, he lamented that the phenomenon is really a problem because many ecotourists especially the whites are given certain privileges to enter certain shrines that are meant only for special notables in the village. This is often orchestrated when these (eco) tourists give out a few bank notes to some selected few; thereby leading to the degradation of our cultural values' he lamented. Field survey also revealed that the government has neglected them in decision making with regard to issues concerning ecotourism development in their locality.

\subsection{Poor Infrastructure}

The French Geographer, Vidal de la Blache (1845-1918) stated that 'Les routes on fait les villes'. This means that 'wherever a road passes, development follows'. About $75 \%$ of the roads along the Babessi-Oku Axis are earth roads. The tarred road within the study area is high way Road Number 11, which passes through Ndop via Baba I, Babessi to Kumbo. Another tarred road passes from Babungo through lbal to Oku (though in a degradable stage). The rest of the roads within the study area are earth. The earth roads are muddy, slippery and almost impassable especially in the heart of the rainy season (Mid-June to late- August). As such, some of the ecotouristic sites are still enclaved to (eco) tourists' access. Such areas include: the Efiame cave, the Mbvek Ngailai cave, and the Kinaki cave among others.

Hence, some of the ecotourism potentials, especially caves and waterfalls, lie idle and unexploited. Some are only accessible during the dry season thereby slowing down the rate of visitation during the rainy season which of course is detrimental to ecotourism activities. These accessibility constraints do have a negative influence on (eco) tourists' arrivals and earnings.

\subsection{Limited Accommodation Facilities}

The comfortability of any (eco) tourist is very important in luring the tourist to stay in that tourism destination as long as he/she likes. Interestingly, the more an ecotourist stays in a tourism destination, the more he/she spends money for lodging, feeding and other safari activities which go a long way to benefit the local community. However, Babessi and Oku do not enjoy all these development privileges because of limited modern and standardized hotels and other catering facilities like restaurants.

Field investigations reveal that poor infrastructure especially lodging facilities is one of the major constraints of the ecotourism sector along the Babessi-Oku Axis as opined by $7.5 \%$ of the population. Within each Sub-division, $7.9 \%$ and $7.3 \%$ in Babessi and Oku respectively opined that poor infrastructural facilities are a deterrent to the ecotourism sector in the region. The few accommodation facilities available such as Kwa 
Kwa guest house, Atlanta Hotel are below national and international standards. Most of the hotels lack constant water flow, swimming poles and wireless internet connections among others.

Culturally, there is the destruction of the cultural values as a constraint to the ecotourism sector along the Babessi-Oku Axis. The ecotourism industry is said to be exploitative. Promoters and ecotourists in the region take snapshots of cultural attractions, heritage and even natural environment without any compensation to the local council, palaces or to the local community. The attractive pictures are produced in magazines and this has reduced the cultural and the environmental landscapes of the BabessiOku Axis. Again, the endangered and rare Bannerman's Turaco and Banded Wattle-eye birds found in OMF are also in pictures in the internet website and all of these reduce the curiosity of (eco) tourists from coming to the region. All these negatively affect the ecotourism sector along the Babessi-Oku Axis.

\section{A WAY FORWARD}

For rural communities whose main sources of livelihood are natural resources such as forests and other vegetal resources, there is the risk of overexploitation of these natural resources. Because most of the people are farmers, loggers, hunters, and gatherers, the pursuit of their economic activities could eventually result in the depletion of natural resources. However, ecotourism provides a more sustainable way of managing these natural resources by fostering conservation through the involvement of local communities, which in turn provides economic incentives to the communities. Agenda 21, which is a blueprint for action by host communities introduced by the 1992 Rio Earth Summit calls for tourism-community interactions that are essential for sustainable development strategies. In view of this, there was recognition of the need to link conservation of resources with the development needs of rural population at the inception of the concept of sustainable development.

\subsection{A Proposed Ecotourism Development Plan for Babessi-Oku Axis}

Given the varieties of ecotouristic potentials that the Babessi-Oku Axis is endowed with, coupled with a plethora of constraints in the development of the sector in the region, there is a possibility of improving its present ecotourism development status so as to boost the ecotourism sector in this region. The improvement of this development status can greatly be enhanced through the development of a well and more comprehensive ecotourism development plan with a well-defined implementation method along the Babessi-Oku Axis. This is illustrated on Fig. 3. This model (Fig. 3) begins with the identification of the various ecotourism sites, to be followed by the creation and rehabilitation of road networks to facilitate accessibility to the various sites. Then a central coordination unit should be created at each of the council branches that will coordinate all the efforts of the other stakeholders and will go a long way to publicize the ecotouristic sites using print broadcasting and emerging digital media as well the creation of awareness through sensitization. The council branches will also create partnerships with other stakeholders in the (eco)tourism sector.

These central coordination units at each council branch together with other stakeholders will further ensure the construction of museums, establishment of souvenir shops and the organisation of cultural manifestations at least twice a year in the two Sub-divisions.

All these will act as a centripetal force in attracting ecotourists into the region and this will lead to income generation since (eco)tourists will be interested in buying gifts for their loved ones thereby stimulating cultural preservation and sustainable livelihood.

The income generated thereof will be used to further reinvest in the ecotourism sector. Here, both the public and private sectors will be involved in the construction and maintenance of roads, hospitals, guest houses restaurants, information and communication technology (ITC) services and the establishment of travelling agencies as well as stepping up security. When all these are put in place, the health, safety and comfortability of the (eco)tourists will be guaranteed, hence making the region an ecotourism cornucopia in the North West Region in particular and Cameroon in general. This will only be compared to other giant ecotourism sites in the world like that of the Viroinval National Park in South Western Belgium or the Great Smoky Mountains National Park in the United States. That notwithstanding, provision has also been made in this model to prevent a decline as observed in the Butler's model of tourism development. This can be achieved by 
making provisions for maintenance and innovations and also through other strategies to pre-empt decline like the introduction of other recreational facilities. All these will lead to economic benefits, enhance poverty alleviation, thereby leading to sustainable livelihood and the enhancement of the conservation of the ecotourism potentials.

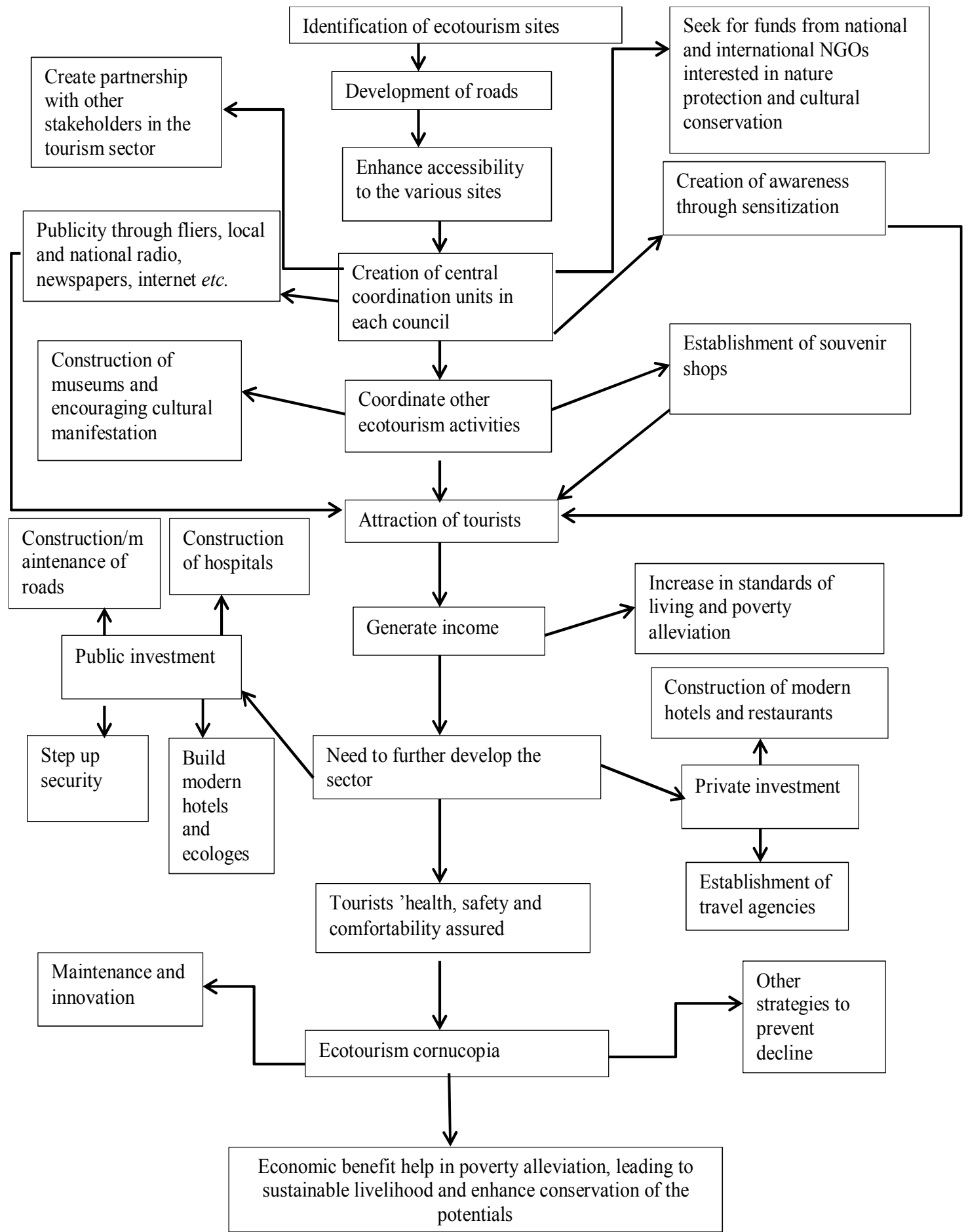

Fig. 3. Ecotourism development model for Babessi-Oku Axis Source: Authors' Conception (2019) 
The appropriate application of the above ecotourism development model along the Babessi-Oku Axis can improve the low income levels of the inhabitants of the region, provide job opportunities to the local inhabitants, diversify the rural economy and above all improve the living conditions and livelihood of the inhabitants. On the part of the State, she will benefit from the taxes paid by the hotel owners, restaurant and tour operators. Also revenue obtained from the (eco)tourists on the developed ecotourism sites and travel agencies will in the long run provide revenue to the tourism management board and the government. This will therefore, be a windwind partnership.

\section{DISCUSSION AND CONCLUSION}

The successive phases of intense deforestation by anthropic activities on the OMF that began since early historic times have ruined well over half of the area and resources of the forest. This devastation was most alarming between 1963 and 1987 when $50 \%$ of forest area was lost. Fogwe and Tchotsoua [23] estimate a $41.6 \%$ forest loss in just five years from 1978 to 1983. Macleod [24] reported 50\% destruction between 1963 and 1983. This escalating rate of forest degradation is indicative of the economic, social, ethnological, and cultural value and exploitation of this forest by the high density montane population that averages $350 \mathrm{inh} / \mathrm{km}^{2}$.

The excruciating harvesting of backs of Prunus africana has been shown further by the studies of Nkeng, et al. [25]. They observed that at least one of the stems is exploited in all diameter classes of this plant species. This exploitation increases with increase in the diameter of the stems. The results have been that "almost all trees with a diameter higher than $10 \mathrm{~cm}$ have been debarked in all the sites, with Oku, Belo and Jakiri showing very high percentages of $99.99 \%, 78.8 \%$, and $70.7 \%$, respectively.

Balgah [26] noted that the proximate causes of loss of biological resources on the Mount Cameroon region are through activities such as large-scale clearing and burning of forests, overharvesting of plants and animals, draining and filling of wetlands, destructive fishing practices and the conversion of wild lands for agricultural and urban land uses among others. Also, in the South Africa context, a range of ecotourism challenges are faced in rural areas which include inadequate infrastructure and services (including roads, energy supply and water provision) as well as low skills of the personnel in the ecotourism sector in the rural areas [27]. Moreover, Ndze [15] noted that the (eco) tourism sector in Cameroon has suffered a number of setbacks in recent years because of terrorist attacks around Waza National Park in Northern Cameroon linked to Nigeria's extremist group, Boko Haram. Nji [28], in his study on the Development of Sustainable Tourism in Cameroon, pointed out that Cameroon in general has a very weak legal and judiciary systems. Little is done by the government to implement the laws that can help to protect the environment, and this affects ecotourism in the country considering that the country's biodiversity is depleted by poachers who hunt wild animals to sell their meat, skin and ivory to traffickers.

Based on the findings of the study and the views of Balgah $[23,25,26,27,28]$, it can said that the constraints of ecotourism development along the Babessi-Oku Axis are similar to those highlighted by other authors above. It is worth pointing out that along the Babessi-Oku Axis, one of the most devastating setbacks to ecotourism development in the region has been the Anglophone crisis (since 2016) that has slowed down ecotourism development in the region and has scared a lot of (eco) tourists from visiting the area. Contrary to what $\mathrm{Nji}$ [28] stated on the weak legal and judiciary system in his study, findings from the field reveal that there are laws and regulations on environmental conservation but unfortunately these laws and regulations are not being obeyed due to the low implementation efforts by the government agencies and the NGOs.

Conclusively, the Babessi-Oku Axis is rich in natural and cultural patrimonies with abundant biodiversity resources and cultural assets for social benefits and economic development. The rich and varied topography, floral and faunal biodiversity as well as cultural diversity of this division provide the primary components necessary in making Babessi and Oku Subdivisions a very fertile terrain capable of attracting ecotourists and promoting ecotourism activities as a whole. This has been hindered by the various constraints to ecotourism development in the area. Making the people living in the fringes to forests especially around the OMF the guardians of the forest resources in the neighbourhood appears to be the most viable, effective, cheaper and long lasting way to manage natural forest resources hence enhancing ecotourism development in the region. Moreover, an ecotourism development model in 
the region has been proposed for the enhancement of ecotourism development in the region.

\section{ACKNOWLEDGEMENT}

The authors are thankful and grateful to the numerous respondents who provided primary and secondary data that were invaluable in conducting in this study.

\section{COMPETING INTERESTS}

Authors have declared that no competing interests exist.

\section{REFERENCES}

1. World Bank. Africa region tourism strategy: Transformation through tourismharnessing tourism for growth and improved livelihoods. Washington, D. C.: World Bank; 2011.

2. UNWTO (United Nations World Tourism Organization). World Tourism Barometer. New York: UNWTO; 2018.

3. Hochachka G, Liu S. Ecotourism in Cross River State, Nigeria. Ontario, Canada: One Sky Canadian Institute of Sustainable Development; 2005.

4. Signé L. Africa's tourism potentials, trends, drivers, opportunities and strategies. brookings, New York: Africa Growth and Initiative Report; 2018.

5. Mushongah J, Scoones I. Livelihood change in rural Zimbabwe over 20 years. Journal of Development Studies. 2012;48: 1241-1257.

6. Schmitz S, Tsobgou DL. Developing tourism products and new partnerships through participatory action research in rural Cameroon. Geogr. Res. 2016;54:2.

7. Harilal V, Tichaawa TM. Ecotourism and alternative livelihood strategies in Cameroon's protected areas. Euro Economica. 2018;1:133-148.

8. Kimengsi JN, Kechia MA, Balgah RA, Pretzsch J, Kwei J. Household's assets dynamics and ecotourism choices in the western highlands of Cameroon. MDPI / Sustainability Journal. 2019;11:1844. DOI: $10.3390 /$ su11071844

9. Tichaawa TM. Business tourism in Africa: The case of Cameroon. Tourism Review International. 2017;21:181-192.

10. Kimbu AN. The challenges of marketing tourism destinations in Central African subregion: The Cameroon example. International Journal of Tourism Research. 2011;13:324-336.

11. Hele P. Tourism in less developed countries. Conference proceedings, Tourism: A catalyst for sustainable development in Africa, April 26-27, Abuja, Nigeria; 2002.

12. Egute TO. Modern law and local tradition in forest heritage conservation in Cameroon: The case of Korup. Ph.D. Thesis, Environmental Sciences Brandenburg University of Technology, Cottbus, Germany; 2012.

13. Fearon JD. Ethnic structure and cultural diversity by country. Journal of Economic Growth. 2003;8:195-222.

14. Kimbu AN. Attainment of MDGs through tourism in Central African sub-region: Implications for local economic development in Cameroon. PASOS. 2012; 10(2):3-16.

15. Ndze TM. Cameroon's tourism ambition: One million tourists by 2020 . Achas Safari. 2016;2.

16. Lambi CM, Dunlop J, Williams R. The Bamendjim Dam of the upper noun valley of Cameroon: No human paradise. Culture and environment: $A$ reader in environmental education. GlasgowScotland, University of Strathcleydes; 1999.

17. Lambi CM. The impact of human activity on land degradation in some highland regions of Cameroon. Implications for development. In Lambi CM. (Ed) Environmental issus: Problems and prospects. Bamenda: Unique Printers and Publishers. 2001;45-66.

18. Tata ES. Wetland exploitation and sustainability challenges in Cameroon: Evidence from Bui-Ngoketunjia Wetlands. African Journal of Social Sciences. 2018; 8(2).

19. Antu M, Zeljko M, Lana K. Tourism infrastructure, recreational facilities and tourism development. Journal of Tourism and Hospitality Management. 2018;24(1): 010205.

20. BUCREP (Bureau Central de Recensement et de Etudes de population). National population and housing census of the republic of Cameroon. Yaounde: BUCREP; 2005.

21. Kometa GC. Landscape ecological mapping and land use evaluation in the upper noun valley, north west region of 
Cameroon. Unpublished M.Sc. Thesis, Department of Geography, University of Buea, Cameroon; 2006.

22. World Ecotourism Summit Final Report. World Ecotourism Summit Final Report. New York: WCS; 2002.

23. Fogwe ZN, Tchotsoua M. Ecological adaptability and slope-trait considerations for water and soil conservation on the vulnerable Oku-Kom plateau in the western highland of Cameroon. Journal of Human Ecology. 2010;30(1):19-25.

24. Macleod AC. Conservation of Oku Montane forest of Cameroon. ICPB, Cambridge. 1987;12.

25. Nkeng PF, Ingram I, Awono A. Assessment of Prunus africana bark exploitation methods and sustainable exploitation in the south west, north-west and Adamaoua regions of Cameroon.
Centre For International Forestry Research (CIFOR) GCP/RAF/408/EC; 2010.

26. Balgah SN, Lambi CM. Exploitation and conservation of biological resources in the mount Cameroon region, Cameroon. Readings in geography. Bamenda: Unique printers; 2001.

ISBBN9956.11.005.1.

27. Groom B, Palmer C. Cost-effective provision of environmental services: The role of relaxing market constraints. Environment and Development Economics. 2010;5(2):219-240.

28. $\mathrm{Nji} \mathrm{CB}$. The development of sustainable tourism in Cameroon: A case of mount cameroon ecotourism organisation. Master of Arts (MA) Thesis in International Cooperation Policy, Ritsumeikan Asian Pacific University; 2012.

(c) 2020 Frederick and Nguh; This is an Open Access article distributed under the terms of the Creative Commons Attribution License (http://creativecommons.org/licenses/by/4.0), which permits unrestricted use, distribution, and reproduction in any medium, provided the original work is properly cited.

Peer-review history:

The peer review history for this paper can be accessed here: http://www.sdiarticle4.com/review-history/60754 